Saudi Journal of Business and Management Studies Abbreviated Key Title: Saudi J Bus Manag Stud ISSN 2415-6663 (Print) |ISSN 2415-6671 (Online) Scholars Middle East Publishers, Dubai, United Arab Emirates Journal homepage: https://saudijournals.com/sibms

Original Research Article

\title{
Improvement of Oil Pack Reject Flexible Packaging on Printing, Lamination and Slitting Processes (A Case Study in PT. XYZ)
}

\author{
Tito Setiawan Nugroho ${ }^{*}$, Rosalendro Eddy Nugroho ${ }^{2}$ \\ ${ }^{1}$ Student of Master Management, Universitas Mercu Buana (UMB), Jakarta Indonesia \\ ${ }^{2}$ Lecture of Master Management, Universitas Mercu Buana (UMB) Jakarta Indonesia
}

\author{
DOI: $10.36348 /$ sjbms.2020.v05i02.001 $\quad$ | Received: 20.01.2020 | Accepted: 27.01.2020 | Published: 08.02.2020 \\ *Corresponding author: Tito Setiawan Nugroho \\ Abstract
}

The production process is inseparable from a problem or reject product. PT. XYZ is a flexible packaging converter manufacturing company that has commitment in maintaining quality to reduce reject products. During the period January 2018 - December 2018 the reject value is still above the standard. This study aims to determine the factors causing the reject products of oil pack at PT. XYZ and proposed improvement to control of reject oil pack products. The results of pareto diagram show the reject that gave the biggest contribution is dirty in the printing process, thickness and wrinkle in the lamination process, and saggy in the slitting process. These four factors were analyzed using a fishbone diagram and then propose improvements for the causes of problems with the $5 \mathrm{~W}$ and $1 \mathrm{H}$ methods. The analysis using cause and effect diagrams found that the main causes are the lack of supervision and inconsistency of the operator; poor maintenance of the engine unit; setting machine parameters and order schedules that not precise; the lack of supply and quality of raw materials. And then propose improvements with the $5 \mathrm{~W} 1 \mathrm{H}$ methods. The proposed improvements are briefing SOP and making engine alarm system; do maintenance, repair or replacement of damaged machine units; setting the machine parameters and order scheduling; monitoring the availability and quality of raw materials. The evaluation results of improvements can reduce the reject in the printing process $45 \%$, the lamination $23 \%$ and the slitting $40 \%$.

Keywords: Product reject, fishbone diagram, $5 \mathrm{~W} 1 \mathrm{H}$.

Copyright @ 2020: This is an open-access article distributed under the terms of the Creative Commons Attribution license which permits unrestricted use, distribution, and reproduction in any medium for non-commercial use (NonCommercial, or CC-BY-NC) provided the original author and source are credited.

\section{INTRODUCTION}

The production process is inseparable from a problem or reject product. A reject product is a product that is produced from a production process that does not meet predetermined quality standards. Rejects can be caused by human, machine, method, material and environmental factors. Reject products can be controlled through quality control [1].

PT. XYZ is a flexible packaging converter manufacturing company. In the manufacturing process manufacturing flexible packaging industry consists of several production processes, namely printing, lamination, and slitting. The company's commitment in maintaining quality is always sought to reduce reject products. During 2018, the problem of production process defects has an average value of $3.78 \%$ or $108 \%$ of the target set at $3.5 \%$ (Figure 1).

At PT. XYZ, there are five types of production groups namely Noodle, Non Noodle, Oil Pack, Sauce Pack, Non Group with different reject standards (Table 1). The most dominant percentage of rejects is in the oil pack because it exceeds twice the standard set.

In producing oil packs consisting of printing, lamination, and slitting processes. The average percentage of reject for each process of oil pack production during January to December 2018 can be seen in Table 2. The lamination process has the highest contribution to the high percentage of reject in the oil pack. 
Table-1: Percentage of average rejects of each group in January-December 2018

\begin{tabular}{|c|c|c|}
\hline Production & Reject (\%) & Standard (\%) \\
\hline Noodle & $2.95 \%$ & $2.5 \%$ \\
\hline Non Noodle & $5.38 \%$ & $5 \%$ \\
\hline Oil Pack & $3.11 \%$ & $1.5 \%$ \\
\hline Sauce Pack & $2.59 \%$ & $2.0 \%$ \\
\hline Non Group & $5.25 \%$ & $5 \%$ \\
\hline
\end{tabular}

Source: Data processed (2018)

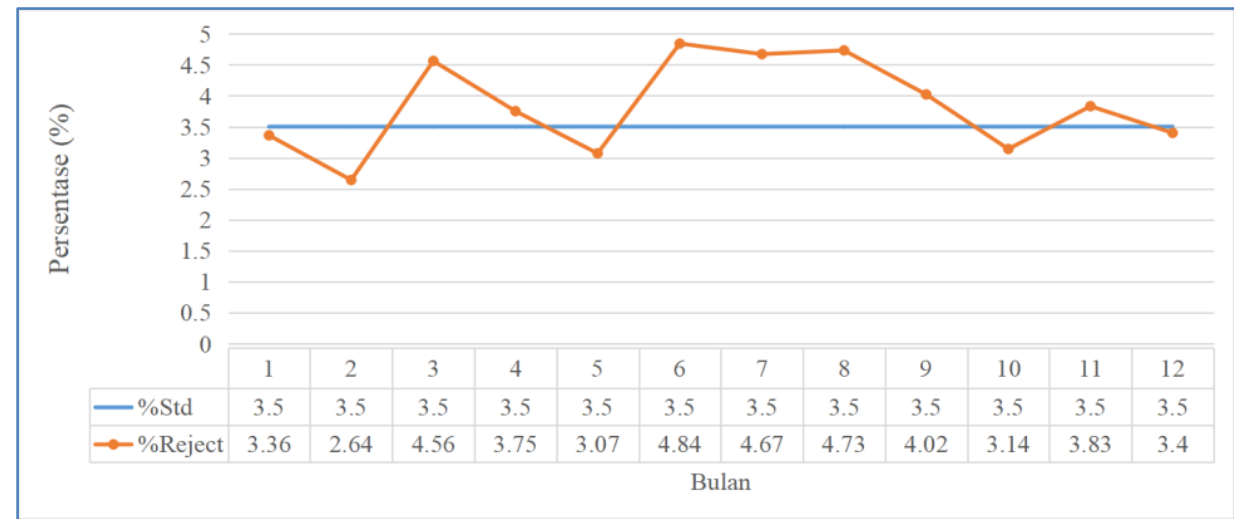

Fig-1: Key Performance Indicator (KPI) of Quality Control (QC) January - December 2018 Source: Data processed (2018)

Table-2: Percentage of average rejects for each oil pack production process in January-December 2018

\begin{tabular}{|c|c|c|}
\hline Proses & Reject (\%) & Standard (\%) \\
\hline Printing & $0.31 \%$ & $1.5 \%$ \\
\cline { 1 - 2 } Laminasi & $2.67 \%$ & \\
\hline Slitting & $0.12 \%$ & \\
\hline
\end{tabular}
Source: Data processed (2018)

The 5W1H method is a method of elaborating what, why, where, when, who and how. The $5 \mathrm{~W} 1 \mathrm{H}$ method is very easy to implement and can lead to new ideas for improvement [2].

\section{Research Objectives}

The objectives of this study are as follows

- To determine the factors causing the reject products of oil pack at PT. XYZ

- To propose improvements to the control of reject oil pack products at PT. XYZ

\section{THEORITICAL REVIEW Quality}

Quality is defined as totality of the characteristics of a product that supports its ability to satisfy the requirements specified or applied [3]. According to Vincent Gaspersz, quality is everything that is able to meet the wishes or needs of consumers [4]. American Society For Quality explain that quality is the totality of features and characteristic of a product or service thatbears on it's ability to satisfy stated or implied need [5].

Juran's Quality Handbook explains that the stages in the quality process known as Juran Trilolgy consist of quality planning, quality control, and quality improvement [6]. Then, according to David Garvin, the dimensions of good product quality consist of performance, features, reliability, conformance to specification, durability, serviceability, aesthetics, fit and finish [7].

\section{Reject Products}

Products according to the Big Indonesian Dictionary are goods or services that are made or added to use or value in the production process and become the final result of the production process. While reject contain deficiencies that cause the value or quality is not good or less perfect. Of the two meanings, if combined together, it means that reject products mean goods or services that are made in the production process but have deficiencies that cause the value or quality to be less good or imperfect. Reject products are products that do not meet proper specifications. This also means it is not in accordance with the established quality standards. Quality conformity assumes that there is a range of values received for each quality specification or characteristic.

Reject are considered as one of the wastes in the manufacturing system which negatively affects the delivery time, cost and product quality which leads to manufacturing companies facing critical situations with customers [8]. The manufacturer must take further action to overcome the problem of the defective product. Defective products can be controlled through quality control. Quality control aims to improve the quality of products produced by a company by reducing the factors of error, product defects, failures, and specifications mismatch. 


\section{Flexible packaging}

Packaging is a technology and material to protect products during the process of distribution, storage, sales and use [9]. Packaging involves designing and producing the container or wrapper for a product. Good packaging can build brand equity and drive sales [10]. Packaging design variables consist of 3 dimensions: graphic design, structure design, and product information [11]. Shimp stated that the design structure is related to the physical features of the packaging, consisting of 3 sub-dimensions: shape, size, and material [12].

Flexible packaging has grown faster than other forms of packaging over the past few decades. Multilayer film technology encourages this growth by allowing special layers with sealing, barrier, or distinguished film layers to meet packaging requirements at a low cost [13]. The process of making flexible packaging from the preparation of raw materials to the consumers is the preparation of raw materials, the printing process, the lamination process, and the slitting process.

The printing process is the process of printing or applying various colors that use ink on the substrate with a printing press [14]. Extrusion lamination is the process of coating a substrate packaging in the form of a plastic film that has been printed on a printing machine with melted polymer resin that has been melted and cooled on a cooling roll or chill roll then pressed using a pressure roll such as making cast film [15]. The slitting process is the last packaging process carried out, namely the process of making plastic packaging labels that are ready to be sent to customers [16].

\section{Fishbone diagram}

Cause and effect diagram developed by Dr. Kaoru Ishikawa, a scientist born in 1915 in Tokyo Japan who was also an alumni of chemical engineering at the University of Tokyo in the 1960s, is widely referred to as the Ishikawa diagram or fishbone diagram [17]. Fishbone diagrams can be used to identify and manage the possible causes of certain effects and then separate the root causes [18].

In the fishbone diagram there are major bones that are the cause, and then there are sub-bones that represent causes in more detail and so on. According to Goetsch and Davis, the causes chosen in making this diagram are categorized into man, methods, machines, materials, and environment (Figure 2) [19].

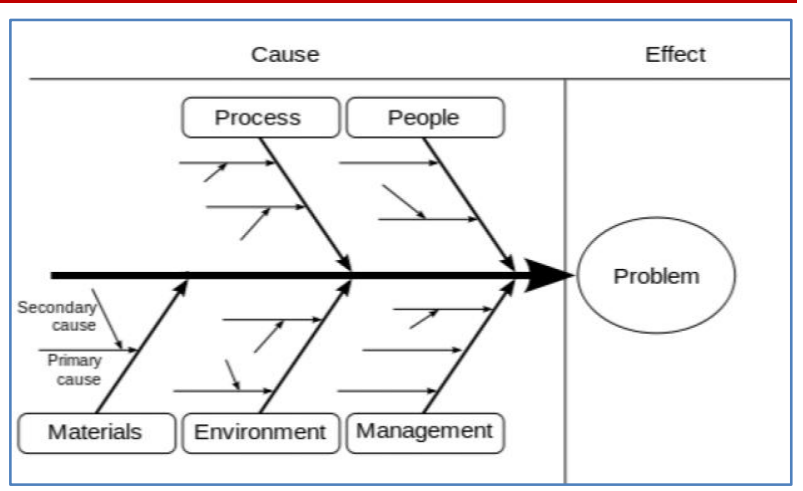

Fig-2: Fishbone diagram

\section{W1H}

The $5 \mathrm{~W} 1 \mathrm{H}$ method is used to analyze information or problem data in all work formats. $5 \mathrm{~W} 1 \mathrm{H}$ (who, what, where, when, why, how) is a method of asking questions about a process or problem taken for improvement. The four letters W (who, what, where, when) and the letter $\mathrm{H}$ are used to understand details, analyze conclusions and assessments to get to the basic facts and guide statements to get to abstraction. The last $\mathrm{W}$ (why) is often asked five times so that one can search to get to the heart of the matter. $5 \mathrm{~W} 1 \mathrm{H}$ from Six Sigma explains the approach that must be followed by understanding and analyzing the process, project or problem for correct improvement [20].

The $5 \mathrm{~W} 1 \mathrm{H}$ method is also called the Kipling method because the term $5 \mathrm{~W} 1 \mathrm{H}$ was originally taken from the Rudyard Kipling poem in 1902. In its application in the production process, we can use this $5 \mathrm{~W} 1 \mathrm{H}$ method to gather information and analyze problems that occur so that it can take appropriate solutions to overcome them. With the existence of this $5 \mathrm{~W} 1 \mathrm{H}$ Analysis, it is expected to simplify the process of analyzing the problems to be carried out.

\section{RESEARCH METHODS}

This research was conducted with a qualitative method with a descriptive research approach. In this study using research variables, namely the product reject oil pack packaging in the process of printing, lamination, and slitting.

\section{Population and sample}

The population in this study is the product reject packaging as a whole in January to December 2018 at PT. XYZ. The sample of this study was taken from the achievement of the reject oil pack product performance in January to December 2018.

\section{Method of collecting data}

Primary data were obtained by collecting data directly obtained through interviews with experts, brainstorming was carried out on production operators, and field observations. Secondary data was obtained from the document study by finding information on the KPI reject report document of the Quality Control 
Department related to the most dominant reject product on oil pack group in the period January to December 2018. Secondary data was also obtained from library studies by collecting information from books, journals, and other data sources related to the research conducted.

\section{METHOD OF DATA ANALYSIS}

a. Analysis of Cause and Effect Diagrams (Fishbone Diagram)

Fishbone diagrams are used to analyze the causes of problems that are grouped into human, machine, material, method, and environmental criteria.

\section{b. Proposed Improvements with $5 \mathrm{~W} 1 \mathrm{H}$}

The $5 \mathrm{~W} 1 \mathrm{H}$ method is used to make improvements using questions as a reference.

What, what's the problem?

Who, who is responsible for this problem?

Where, where did the problem occur?

When, when is the planning to fix the problem done?

Why, why does the problem occur?

How, how to overcome the problem?

\section{DATA ANALYSIS}

Collect Data and Determine Priorities

\section{a. Reject Oil Pack in the Printing Process}

In the printing process, there are eight categories of reject products that are blocking, nonstandard colors, shadow, dirty, scratch, ink blotch, ink bald, and dash images (Figure 3a). Of the eight types of reject printing during the period January December 2018 none exceeded the standard. However, with the Pareto diagram (Figure $3 b$ ) it is seen that the most dominant reject category is dirty with a cumulative percentage value of $94.01 \%$ (more than $80 \%)$.

\section{b. Reject Oil Pack in the Lamination Process}

In the process of lamination, there are several classifications of reject lamination products namely wrinkle, thickness, clear, shriveled, delamination, sticky and scratch spot (Figure 4). Through the pareto diagram, the most dominant is wrinkle and thickness with a cumulative percentage of $93.66 \%$ (more than $80 \%)$.

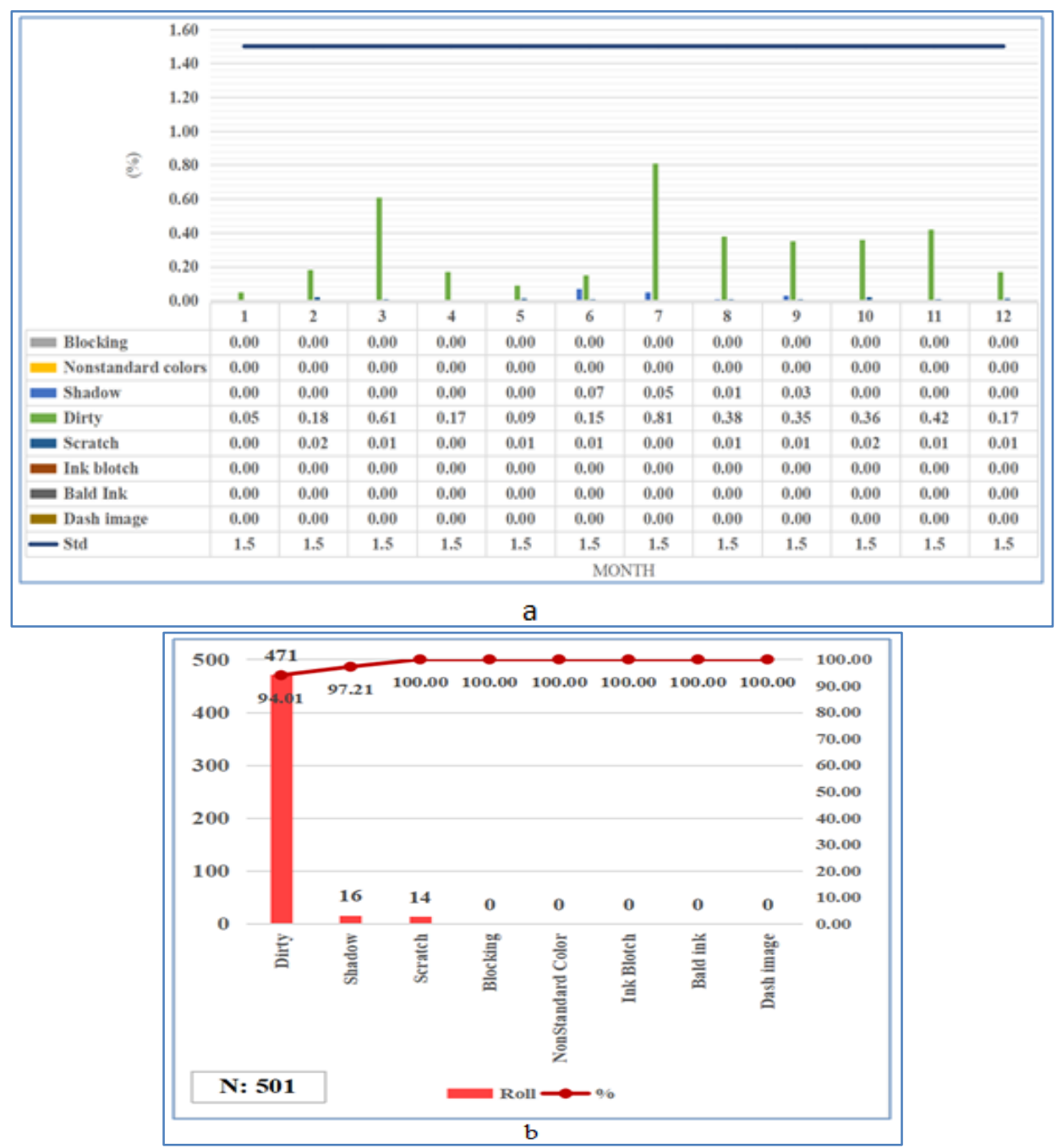

Fig-3: (a) Percentage of reject oil packs products in the printing process from January to December 2018. (b) Pareto diagram of reject oil pack in the printing process from January to December 2018 Source: Data processed (2018) 


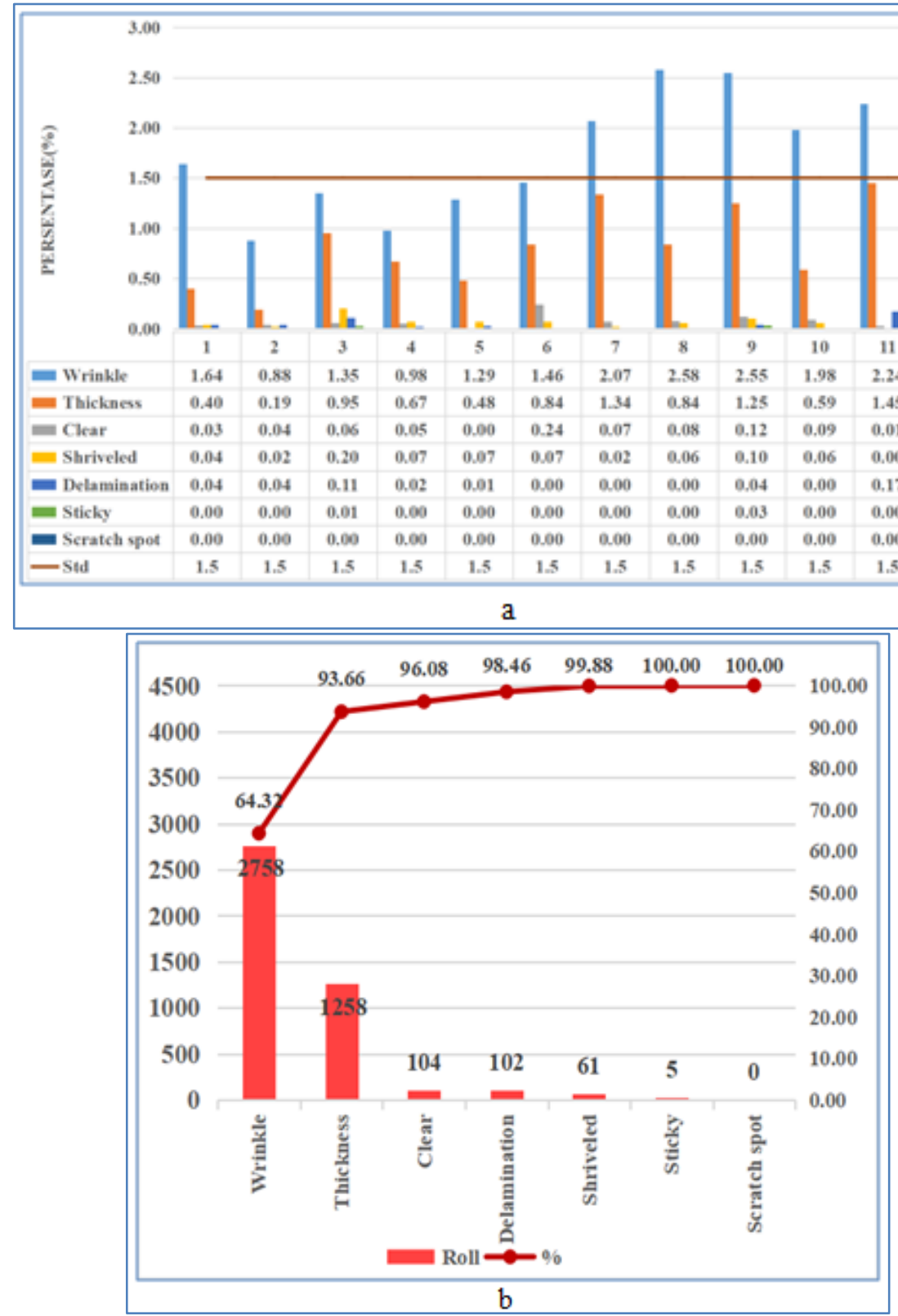

Fig-4: Percentage of reject oil pack in the lamination process from January to December 2018 Source: Data processed (2018)

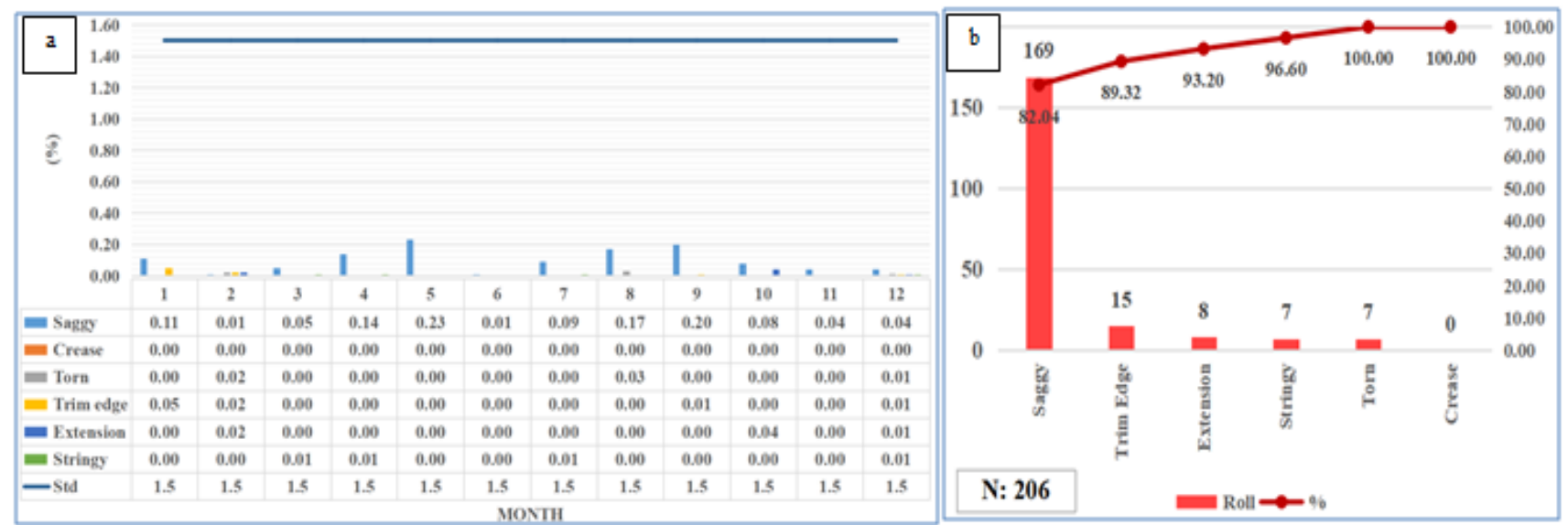

Fig-5: (a) Percentage of reject oil packs products in the slitting process from January to December 2018. (b) Pareto diagram of reject oil pack in the slitting process from January to December 2018 Source: Data processed (2018) 


\section{a. Reject Oil Pack in the Slitting Process}

The types of reject in the slitting process are saggy, crease, torn, trim edge, extension, and stringy (Figure 5a). There is no reject that exceeds the standard, but through the pareto diagram (Figure $5 b$ ) can be seen that the reject saggy is dominant with a cumulative percentage value of $82.04 \%$ (more than $80 \%$ ).

\section{Analysis of Cause and Effect Diagrams (Fishbone} Diagrams)

This analysis is done by direct observation to the field and conducting interviews and discussions with related employees. The interviews and discussions aim to find out the possible causes of not achieving the target of oil packs reject.

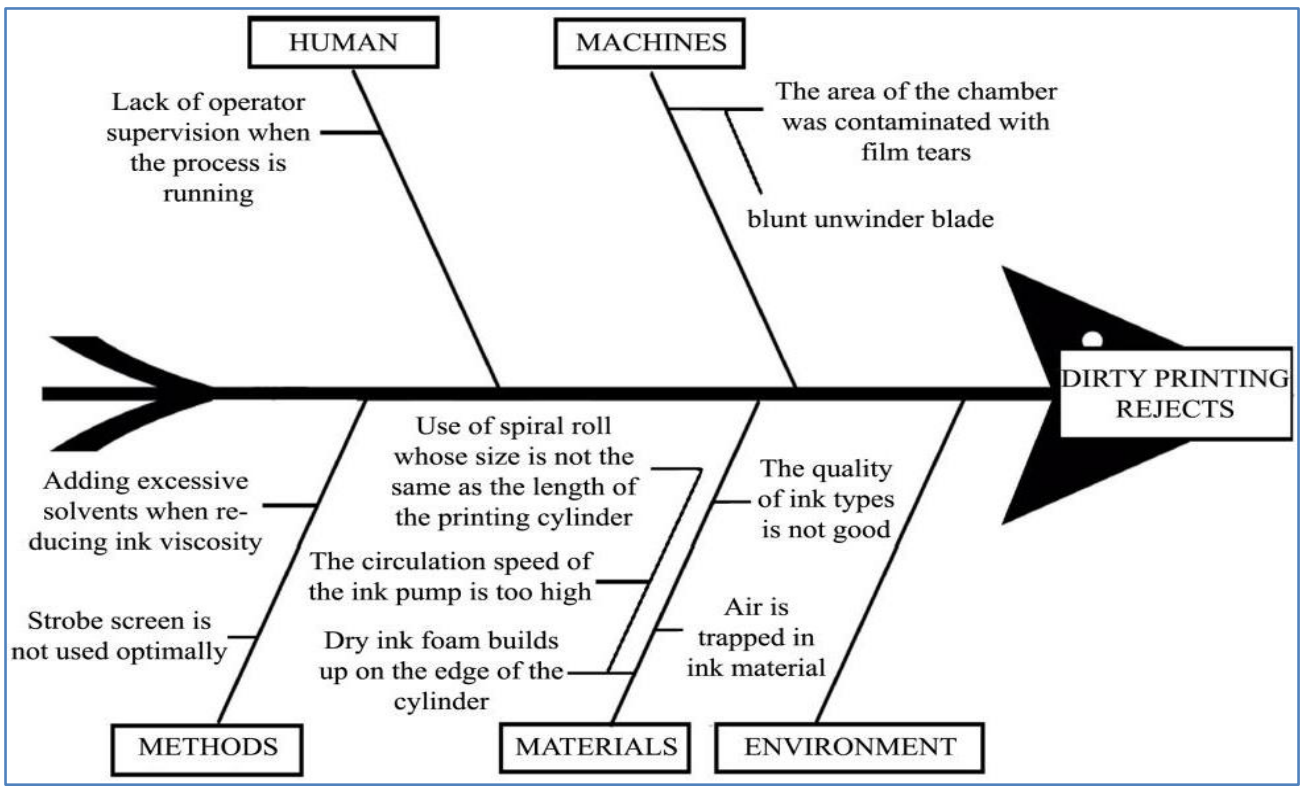

Fig-6: Cause and effect diagram of dirty reject in the printing process

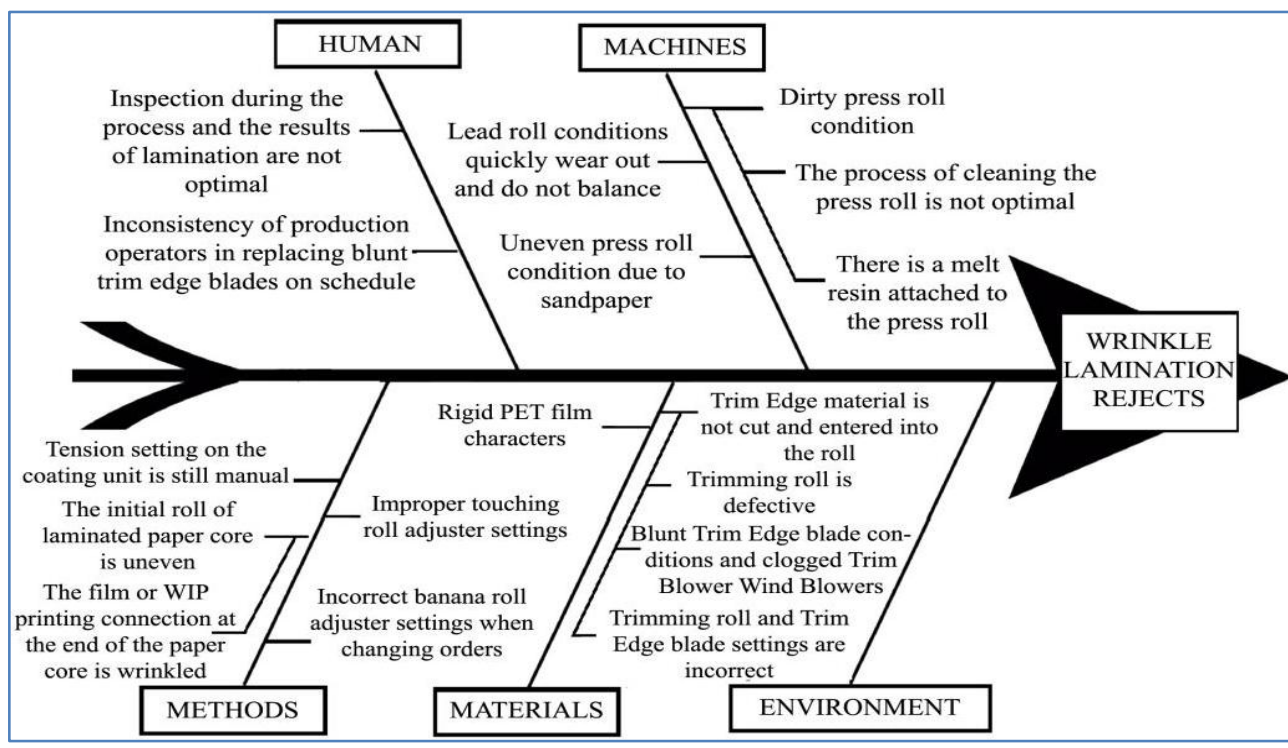

Fig-7: Cause and effect diagram of wrinkle reject in the lamination process 


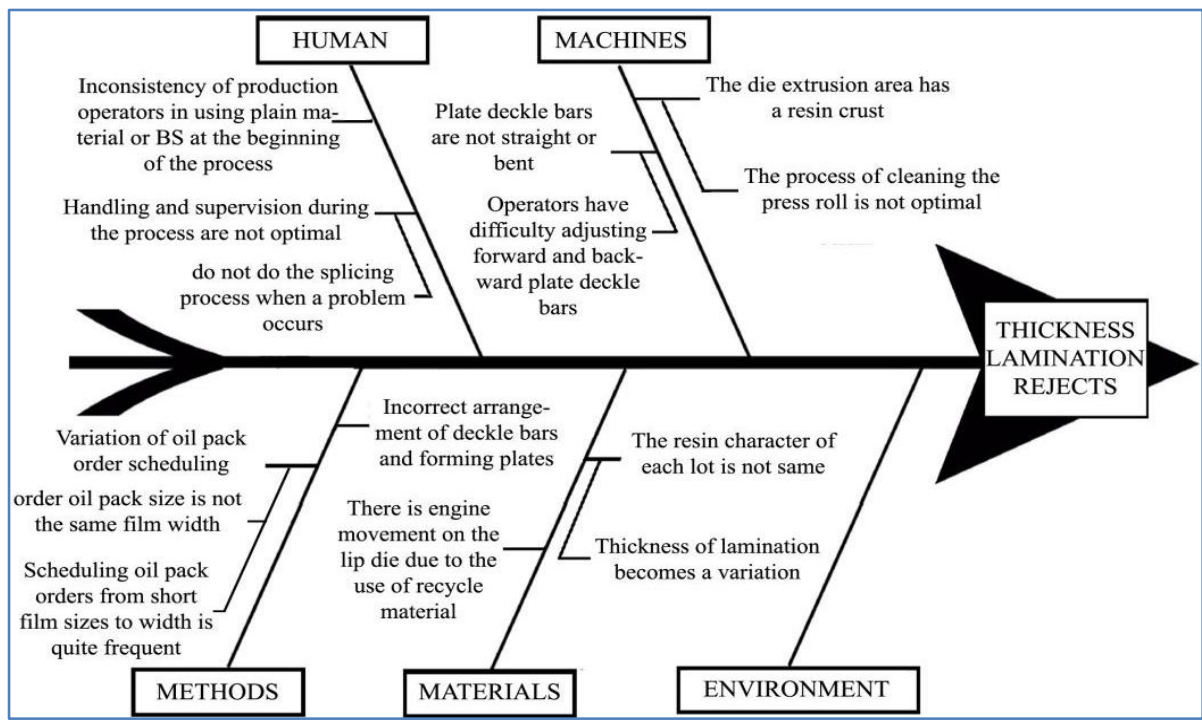

Fig-8: Cause and effect diagram of thickness reject in the lamination process

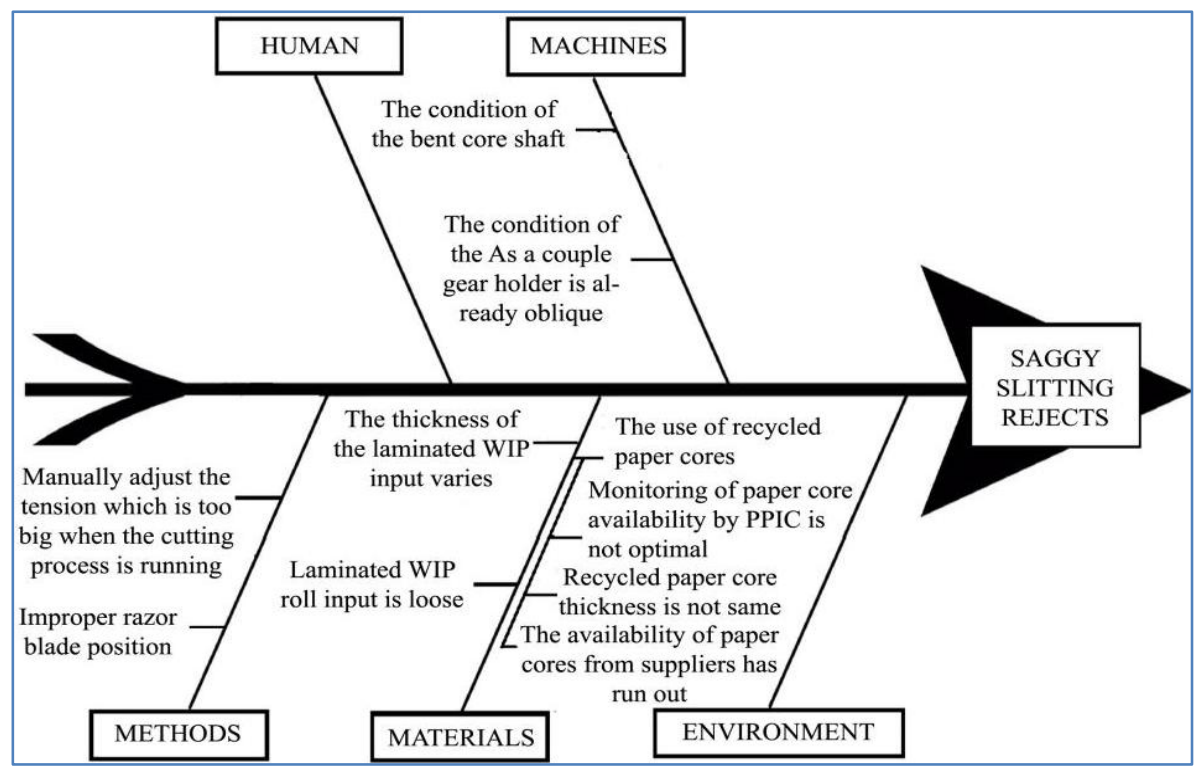

Fig-9: Cause and effect diagram of saggy reject in the slitting process

\section{DISCUSSION}

There are four factors that influence the high dirty printing reject, namely human factors, machine factors, method factors, and material factors. The human factor is the lack of operator supervision during the road process. The engine factor is caused by the area of the chamber being contaminated with a tear. The method factor is that the strobe monitor screen is not used maximally and the addition of excessive solvents when decreasing ink viscosity. Material factors are the dry foam of ink that has accumulated on the edge of the cylinder, the air trapped in the ink, and the ink quality is not good.

The causes of wrinkle and thickness lamination reject is also influenced by four factors. The human factor is that the inspection during the process is not optimal and the inconsistency of production operators in the replacement of trim edge blades. The machine factor is caused by dirty press roll, lead roll condition which wears out quickly and unbalanced. The method factor is setting the tension on the coating unit is still manual, the initial roll of the laminated core is not flat, the adjustment of the touching roll adjuster is incorrect, and the adjustment of the banana roll adjuster is incorrect. Fator material is a trim edge material that is not cut.

In saggy slitting reject is caused by 3 factors. The engine factor is due to the bent As condition and the oblique couple gear holder condition. Factors of the method are setting the tension that is too large manually when the cutting process is running and the razor blade position is not right. Material factors are caused by the use of recycled paper cores and laminated WIP input thickness.

Repair Analysis Using 5W + 1H 
Tito Setiawan Nugroho \& Rosalendro Eddy Nugroho; Saudi J Bus Manag Stud, Feb., 2020; 5(2): 99-111

Table-3: Improvements of the printing processes with $5 \mathrm{~W} 1 \mathrm{H}$

\begin{tabular}{|c|c|c|c|c|c|c|}
\hline Causes & What & Why & How & Who & When & Where \\
\hline \multirow[t]{3}{*}{ Human } & \multirow[t]{3}{*}{$\begin{array}{l}\text { Lack of operator } \\
\text { supervision } \\
\text { when the process } \\
\text { is running }\end{array}$} & $\begin{array}{l}\text { Operators are less concerned } \\
\text { with the results of the printing } \\
\text { process produced and do not } \\
\text { fulfill the process control } \\
\text { obligations according to the } \\
\text { SOP }\end{array}$ & $\begin{array}{l}\text { Conduct a briefing to the } \\
\text { operator regarding the } \\
\text { printing machine SOP } \\
\text { (FPT-PRD-001) } \\
\text { regarding the obligation } \\
\text { to monitor the printing } \\
\text { process }\end{array}$ & SPV printing & $\begin{array}{l}\text { Periodically } \\
\text { once a week }\end{array}$ & $\begin{array}{l}\text { Printing } \\
\text { production } \\
\text { area }\end{array}$ \\
\hline & & \multirow[t]{2}{*}{$\begin{array}{l}\text { The absence of a warning } \\
\text { system on the engine }\end{array}$} & $\begin{array}{l}\text { Create an OPL system } \\
\text { (one point lesson) to } \\
\text { remind operators }\end{array}$ & SPV printing & Januari 2019 & $\begin{array}{l}\text { Printing } \\
\text { production } \\
\text { area }\end{array}$ \\
\hline & & & $\begin{array}{c}\text { Make an alarm system on } \\
\text { the machine if a problem } \\
\text { occurs }\end{array}$ & Engineering & Januari 2019 & $\begin{array}{l}\text { OSG printing } \\
\text { machine }\end{array}$ \\
\hline \multirow[t]{2}{*}{ Machines } & \multirow[t]{2}{*}{$\begin{array}{l}\text { The area of the } \\
\text { chamber was } \\
\text { contaminated } \\
\text { with film tears } \\
\text { due to a blunt } \\
\text { unwinder blade }\end{array}$} & $\begin{array}{c}\text { The PM (preventive } \\
\text { maintenance) schedule is } \\
\text { delayed because orders have } \\
\text { increased }\end{array}$ & $\begin{array}{c}\text { Review the PM schedule } \\
\text { that has been set every } 1 \\
\text { month and made a joint } \\
\text { commitment to fit the } \\
\text { plan }\end{array}$ & $\begin{array}{l}\text { PPIC and } \\
\text { engineering }\end{array}$ & Januari 2019 & $\begin{array}{l}\text { OSG printing } \\
\text { machine }\end{array}$ \\
\hline & & $\begin{array}{c}\text { Independent operator } \\
\text { monitoring of machine } \\
\text { maintenance is lacking because } \\
\text { the AM (autonomous } \\
\text { maintenance) system is not } \\
\text { running }\end{array}$ & $\begin{array}{l}\text { Briefing operators to run } \\
\text { the AM system by filling } \\
\text { out the form provided }\end{array}$ & SPV printing & $\begin{array}{l}\text { Periodically } \\
\text { once a week }\end{array}$ & $\begin{array}{l}\text { OSG printing } \\
\text { machine }\end{array}$ \\
\hline \multirow[t]{3}{*}{ Methods } & $\begin{array}{l}\text { Adding } \\
\text { excessive } \\
\text { solvents when } \\
\text { reducing ink } \\
\text { viscosity }\end{array}$ & Foam on the surface of the ink & $\begin{array}{c}\text { Adding solvents or } \\
\text { solvents little by little } \\
\text { and checking the } \\
\text { viscosity after adding the } \\
\text { solvent with zhan cup } 3 \\
\text { gauge }\end{array}$ & Operator & $\begin{array}{l}\text { Every oil pack } \\
\text { production } \\
\text { process }\end{array}$ & $\begin{array}{l}\text { OSG printing } \\
\text { machine }\end{array}$ \\
\hline & \multirow[t]{2}{*}{$\begin{array}{l}\text { Strobe screen is } \\
\text { not used } \\
\text { optimally }\end{array}$} & \multirow[t]{2}{*}{$\begin{array}{l}\text { The results of the oil pack } \\
\text { printing process are not } \\
\text { controlled }\end{array}$} & $\begin{array}{l}\text { During the process the } \\
\text { operator must monitor } \\
\text { and monitor the print } \\
\text { quality results in front of } \\
\text { the strobe monitor screen }\end{array}$ & Operator & $\begin{array}{l}\text { Every oil pack } \\
\text { production } \\
\text { process }\end{array}$ & $\begin{array}{l}\text { OSG printing } \\
\text { machine }\end{array}$ \\
\hline & & & $\begin{array}{l}\text { Make a shift schedule to } \\
\text { control the strobe } \\
\text { monitor every two hours }\end{array}$ & SPV printing & Januari 2019 & $\begin{array}{l}\text { OSG printing } \\
\text { machine }\end{array}$ \\
\hline
\end{tabular}

\begin{tabular}{|c|c|c|c|c|c|c|}
\hline Causes & What & Why & How & Who & When & Where \\
\hline \multirow[t]{7}{*}{ Materials } & \multirow{3}{*}{$\begin{array}{l}\text { Dry ink foam } \\
\text { builds up on the } \\
\text { edge of the } \\
\text { cylinder }\end{array}$} & $\begin{array}{l}\text { The circulation speed of } \\
\text { the ink pump is too high }\end{array}$ & $\begin{array}{l}\text { Set the circulation speed of the ink } \\
\text { pump to the low position }\end{array}$ & Operator & $\begin{array}{l}\text { Every oil pack } \\
\text { production } \\
\text { process }\end{array}$ & $\begin{array}{c}\text { OSG } \\
\text { printing } \\
\text { machine }\end{array}$ \\
\hline & & \multirow[t]{2}{*}{$\begin{array}{l}\text { Use of spiral roll whose } \\
\text { size is not the same as the } \\
\text { length of the printing } \\
\text { cylinder }\end{array}$} & $\begin{array}{l}\text { Collecting spiral roll data that is } \\
\text { not the same size as the printed } \\
\text { cylinder and standardizing the } \\
\text { length of the spiral roll }\end{array}$ & $\begin{array}{c}\text { SPV } \\
\text { printing }\end{array}$ & Januari 2019 & $\begin{array}{c}\text { OSG } \\
\text { printing } \\
\text { machine }\end{array}$ \\
\hline & & & Make a spiral roller purchasel & Purchasing & Februari 2019 & $\begin{array}{c}\text { OSG } \\
\text { printing } \\
\text { machine }\end{array}$ \\
\hline & \multirow[t]{2}{*}{$\begin{array}{l}\text { Air is trapped in } \\
\text { ink material }\end{array}$} & $\begin{array}{c}\text { Ink availability in the } \\
\text { receptacle at the minimum } \\
\text { level }\end{array}$ & $\begin{array}{l}\text { Control the ink level in the } \\
\text { reservoir }\end{array}$ & Operator & $\begin{array}{l}\text { Every oil pack } \\
\text { production } \\
\text { process } \\
\end{array}$ & $\begin{array}{c}\text { OSG } \\
\text { printing } \\
\text { machine }\end{array}$ \\
\hline & & The ink pump is leaking & $\begin{array}{l}\text { Replace the leaky ink pump in } \\
\text { good condition }\end{array}$ & Operator & $\begin{array}{l}\text { Every oil pack } \\
\text { production } \\
\text { process }\end{array}$ & $\begin{array}{c}\text { OSG } \\
\text { printing } \\
\text { machine }\end{array}$ \\
\hline & \multirow[t]{2}{*}{$\begin{array}{l}\text { The quality of } \\
\text { ink types is not } \\
\text { good }\end{array}$} & \multirow[t]{2}{*}{$\begin{array}{c}\text { Foam on the surface of the } \\
\text { ink }\end{array}$} & $\begin{array}{c}\text { Do not use ink and replace } \\
\text { alternative ink from other } \\
\text { suppliers } \\
\end{array}$ & Operator & Januari 2019 & $\begin{array}{c}\text { OSG } \\
\text { printing } \\
\text { machine }\end{array}$ \\
\hline & & & $\begin{array}{l}\text { Inform the supplier to make } \\
\text { improvements to the ink quality }\end{array}$ & QC & Januari 2019 & $\begin{array}{c}\text { OSG } \\
\text { printing } \\
\text { machine }\end{array}$ \\
\hline
\end{tabular}


Tito Setiawan Nugroho \& Rosalendro Eddy Nugroho; Saudi J Bus Manag Stud, Feb., 2020; 5(2): 99-111

Table-4: Improvements of the lamination processes with $5 \mathrm{~W} 1 \mathrm{H}$

\begin{tabular}{|c|c|c|c|c|c|c|}
\hline Causes & What & Why & How & Who & When & Where \\
\hline \multirow[t]{7}{*}{ Human } & \multirow[t]{3}{*}{$\begin{array}{l}\text { Handling and } \\
\text { supervision and } \\
\text { inspection during } \\
\text { the process and } \\
\text { the results of } \\
\text { lamination are } \\
\text { not optimal }\end{array}$} & $\begin{array}{l}\text { Operators are less } \\
\text { concerned about the results } \\
\text { of lamination produced } \\
\text { and do not meet the } \\
\text { inspection obligations of } \\
\text { the extrusion process } \\
\text { according to the SOP }\end{array}$ & $\begin{array}{l}\text { Conduct a briefing to the operator } \\
\text { regarding the SOP of the extrusion } \\
\text { machine (WI / FPT-PRD-005) } \\
\text { regarding the obligation to check the } \\
\text { conditions during the process and the } \\
\text { results of the lamination }\end{array}$ & $\begin{array}{c}\text { SPV } \\
\text { lamination }\end{array}$ & $\begin{array}{l}\text { Periodical } \\
\text { ly once a } \\
\text { week }\end{array}$ & $\begin{array}{l}\text { Lamination } \\
\text { production } \\
\text { area }\end{array}$ \\
\hline & & \multirow[t]{2}{*}{$\begin{array}{l}\text { There is no warning } \\
\text { system attached to the } \\
\text { lamination machine }\end{array}$} & $\begin{array}{c}\text { Creating an OPL (one point lesson) } \\
\text { system for handling problems and } \\
\text { 3D writing (Seen - Touched - } \\
\text { Repaired) }\end{array}$ & $\begin{array}{c}\text { SPV } \\
\text { lamination }\end{array}$ & $\begin{array}{c}\text { Januari } \\
2019\end{array}$ & $\begin{array}{l}\text { Lamination } \\
\text { production } \\
\text { area }\end{array}$ \\
\hline & & & $\begin{array}{c}\text { Make an alarm system on the } \\
\text { laminate machine if a problem } \\
\text { occurs }\end{array}$ & $\begin{array}{c}\text { Engineerin } \\
\mathrm{g}\end{array}$ & $\begin{array}{c}\text { Januari } \\
2019\end{array}$ & $\begin{array}{l}\text { Extrusion } \\
\text { lamination } \\
\text { machine } 5 \\
\end{array}$ \\
\hline & \multirow{2}{*}{$\begin{array}{l}\text { Inconsistency of } \\
\text { production } \\
\text { operators in } \\
\text { replacing blunt } \\
\text { trim edge blades } \\
\text { on schedule }\end{array}$} & \multirow[t]{2}{*}{$\begin{array}{l}\text { The operator is late in } \\
\text { replacing the trim edge } \\
\text { blade }\end{array}$} & $\begin{array}{l}\text { Make a checklist of trim edge blade } \\
\text { replacement list on form F06 / FPT- } \\
\text { PRD-005 }\end{array}$ & $\begin{array}{c}\text { SPV } \\
\text { lamination }\end{array}$ & $\begin{array}{c}\text { Januari } \\
2019\end{array}$ & $\begin{array}{c}\text { Extrusion } \\
\text { lamination } \\
\text { machine } 5 \\
\end{array}$ \\
\hline & & & $\begin{array}{l}\text { Make OPL (one point lesson) about } \\
\text { the TE blade replacement schedule } \\
\text { and taped in an easily visible area of } \\
\text { the machine }\end{array}$ & $\begin{array}{c}\text { SPV } \\
\text { lamination }\end{array}$ & $\begin{array}{c}\text { Januari } \\
2019\end{array}$ & $\begin{array}{l}\text { Extrusion } \\
\text { lamination } \\
\text { machine } 5\end{array}$ \\
\hline & \multirow{2}{*}{$\begin{array}{l}\text { Inconsistency of } \\
\text { production } \\
\text { operators in } \\
\text { using plain } \\
\text { material or BS at } \\
\text { the beginning of } \\
\text { the process }\end{array}$} & \multirow[t]{2}{*}{$\begin{array}{l}\text { Lamination results in } \\
\text { thickness variations }\end{array}$} & $\begin{array}{l}\text { Briefing operators about SOPs for } \\
\text { extrusion machines (WI / FPT-PRD- } \\
\text { 005) regarding the obligation to use } \\
\text { plain materials when changing } \\
\text { orders with different thickness }\end{array}$ & $\begin{array}{c}\text { SPV } \\
\text { lamination }\end{array}$ & $\begin{array}{l}\text { Periodical } \\
\text { ly once a } \\
\text { week }\end{array}$ & $\begin{array}{l}\text { Lamination } \\
\text { production } \\
\text { area }\end{array}$ \\
\hline & & & $\begin{array}{l}\text { Checking the thickness of the cutting } \\
\text { area and the edge area is tightened to } \\
2.5 \mathrm{~cm}\end{array}$ & QC & $\begin{array}{c}\text { Januari } \\
2019\end{array}$ & Laboratorium \\
\hline \multirow[t]{8}{*}{$\begin{array}{l}\text { Machine } \\
\text { s }\end{array}$} & $\begin{array}{l}\text { Dirty press roll } \\
\text { condition }\end{array}$ & $\begin{array}{l}\text { The process of cleaning } \\
\text { the press roll when the } \\
\text { machine stops or changes } \\
\text { the order is not optimal }\end{array}$ & $\begin{array}{l}\text { Clean the dirt on the press roll } \\
\text { carefully and thoroughly }\end{array}$ & Operator & $\begin{array}{c}\text { Each oil } \\
\text { pack } \\
\text { lamination }\end{array}$ & $\begin{array}{l}\text { Extrusion } \\
\text { lamination } \\
\text { machine } 5\end{array}$ \\
\hline & \multirow{2}{*}{$\begin{array}{l}\text { Lead roll } \\
\text { conditions } \\
\text { quickly wear out } \\
\text { and do not } \\
\text { balance }\end{array}$} & \multirow[t]{2}{*}{$\begin{array}{l}\text { Pull the groove of the film } \\
\text { becomes unbalanced }\end{array}$} & $\begin{array}{l}\text { Doing replacement lead roll which } \\
\text { used to be smooth type into screw } \\
\text { type }\end{array}$ & $\begin{array}{c}\text { SPV } \\
\text { lamination }\end{array}$ & $\begin{array}{c}\text { Januari } \\
2019\end{array}$ & $\begin{array}{l}\text { Extrusion } \\
\text { lamination } \\
\text { machine } 5 \\
\end{array}$ \\
\hline & & & $\begin{array}{l}\text { Make repairs on the As Lead Roll } \\
\text { holder that is worn }\end{array}$ & $\begin{array}{c}\text { Engineerin } \\
\mathrm{g}\end{array}$ & $\begin{array}{c}\text { Januari } \\
2019\end{array}$ & $\begin{array}{l}\text { Extrusion } \\
\text { lamination } \\
\text { machine } 5 \\
\end{array}$ \\
\hline & \multirow[t]{2}{*}{$\begin{array}{l}\text { Uneven press roll } \\
\text { condition due to } \\
\text { sandpaper }\end{array}$} & \multirow[t]{2}{*}{$\begin{array}{l}\text { The film flow on the press } \\
\text { roll becomes unstable and } \\
\text { uneven }\end{array}$} & $\begin{array}{l}\text { Replace the press roll with } \\
\text { conditions that are still flat }\end{array}$ & Operator & $\begin{array}{c}\text { Januari } \\
2019\end{array}$ & $\begin{array}{l}\text { Extrusion } \\
\text { lamination } \\
\text { machine } 5\end{array}$ \\
\hline & & & $\begin{array}{l}\text { Make a press roll replacement } \\
\text { schedule every } 2 \text { weeks }\end{array}$ & $\begin{array}{c}\text { SPV } \\
\text { lamination }\end{array}$ & $\begin{array}{c}\text { Januari } \\
2019\end{array}$ & $\begin{array}{l}\text { Extrusion } \\
\text { lamination } \\
\text { machine } 5 \\
\end{array}$ \\
\hline & \multirow[t]{2}{*}{$\begin{array}{c}\text { The die extrusion } \\
\text { area has a resin } \\
\text { crust }\end{array}$} & \multirow[t]{2}{*}{$\begin{array}{l}\text { The process of cleaning } \\
\text { the press roll when the } \\
\text { machine stops or changes } \\
\text { the order is not optimal }\end{array}$} & $\begin{array}{l}\text { Perform a thorough and periodic } \\
\text { cleaning die with a triangular copper } \\
\text { plug and rotate the manifold in and } \\
\text { out several times so that the die wall } \\
\text { is perfectly clean }\end{array}$ & Operator & $\begin{array}{c}\text { Januari } \\
2019\end{array}$ & $\begin{array}{l}\text { Extrusion } \\
\text { lamination } \\
\text { machine } 5\end{array}$ \\
\hline & & & $\begin{array}{l}\text { Split die and die cleaning if the die } \\
\text { plug method is not able to handle } \\
\text { reject thickness }\end{array}$ & $\begin{array}{c}\text { Engineerin } \\
\mathrm{g}\end{array}$ & $\begin{array}{c}\text { Januari } \\
2019\end{array}$ & $\begin{array}{l}\text { Extrusion } \\
\text { lamination } \\
\text { machine } 5 \\
\end{array}$ \\
\hline & $\begin{array}{l}\text { Plate deckle bars } \\
\text { are not straight or } \\
\text { bent }\end{array}$ & $\begin{array}{l}\text { Operators have difficulty } \\
\text { adjusting forward and } \\
\text { backward plate deckle bars }\end{array}$ & $\begin{array}{l}\text { Replace the deckle bar plate with the } \\
\text { straight one }\end{array}$ & $\begin{array}{c}\text { SPV } \\
\text { lamination }\end{array}$ & $\begin{array}{c}\text { Januari } \\
2019\end{array}$ & $\begin{array}{l}\text { Extrusion } \\
\text { lamination } \\
\text { machine } 5\end{array}$ \\
\hline Causes & What & Why & How & Who & When & Where \\
\hline \multirow[t]{5}{*}{ Methods } & $\begin{array}{l}\text { Tension setting } \\
\text { on the coating } \\
\text { unit is still } \\
\text { manual }\end{array}$ & $\begin{array}{l}\text { Oil film printing material } \\
\text { with different character }\end{array}$ & $\begin{array}{l}\text { Make modifications to the coating } \\
\text { unit so that it can adjust the tension } \\
\text { automatically }\end{array}$ & $\begin{array}{c}\text { Engineerin } \\
\mathrm{g}\end{array}$ & $\begin{array}{c}\text { Januari } \\
2019\end{array}$ & $\begin{array}{l}\text { Extrusion } \\
\text { lamination } \\
\text { machine } 5\end{array}$ \\
\hline & \multirow[t]{2}{*}{$\begin{array}{l}\text { The initial roll of } \\
\text { laminated paper } \\
\text { core is uneven }\end{array}$} & \multirow[t]{2}{*}{$\begin{array}{l}\text { The film or WIP printing } \\
\text { connection at the end of the } \\
\text { paper core is wrinkled }\end{array}$} & $\begin{array}{c}\text { Splicing immediately if at the end } \\
\text { of the core WIP printing there is } \\
\text { potential for wrinkles }\end{array}$ & Operator & $\begin{array}{c}\text { Each oil } \\
\text { pack } \\
\text { lamination } \\
\end{array}$ & $\begin{array}{l}\text { Extrusion } \\
\text { lamination } \\
\text { machine } 5 \\
\end{array}$ \\
\hline & & & $\begin{array}{c}\text { Adjust pressure on the gap rewinder } \\
\text { to improve the initial roll condition } \\
\text { of the laminated core }\end{array}$ & Operator & $\begin{array}{c}\text { Each oil } \\
\text { pack } \\
\text { lamination } \\
\end{array}$ & $\begin{array}{l}\text { Extrusion } \\
\text { lamination } \\
\text { machine } 5 \\
\end{array}$ \\
\hline & $\begin{array}{c}\text { Improper } \\
\text { touching roll } \\
\text { adjuster settings }\end{array}$ & Uneven film flow & $\begin{array}{l}\text { Adjust the touching roll adjuster } \\
\text { correctly and quickly when splicing }\end{array}$ & Operator & $\begin{array}{c}\text { Each oil } \\
\text { pack } \\
\text { lamination } \\
\end{array}$ & $\begin{array}{l}\text { Extrusion } \\
\text { lamination } \\
\text { machine } 5\end{array}$ \\
\hline & $\begin{array}{l}\text { Incorrect banana } \\
\text { roll adjuster }\end{array}$ & Uneven film flow & $\begin{array}{l}\text { Adjust the banana roll adjuster by } \\
\text { raising the speed slowly and when }\end{array}$ & Operator & $\begin{array}{l}\text { Each oil } \\
\text { pack }\end{array}$ & $\begin{array}{c}\text { Extrusion } \\
\text { lamination }\end{array}$ \\
\hline
\end{tabular}


Tito Setiawan Nugroho \& Rosalendro Eddy Nugroho; Saudi J Bus Manag Stud, Feb., 2020; 5(2): 99-111

\begin{tabular}{|c|c|c|c|c|c|c|}
\hline & $\begin{array}{l}\text { settings when } \\
\text { changing orders }\end{array}$ & & $\begin{array}{l}\text { the film flow is good the splicing is } \\
\text { done immediately }\end{array}$ & & lamination & machine 5 \\
\hline & $\begin{array}{l}\text { Variation of oil } \\
\text { pack order } \\
\text { scheduling }\end{array}$ & $\begin{array}{l}\text { Scheduling oil pack orders } \\
\text { from short film sizes to } \\
\text { width is quite frequent }\end{array}$ & $\begin{array}{l}\text { Coordinate with the PPIC team } \\
\text { during the meeting schedule, } \\
\text { ensuring oil pack orders are } \\
\text { arranged from long to short film } \\
\text { sizes }\end{array}$ & $\begin{array}{l}\text { PPIC and } \\
\text { SPV } \\
\text { lamination }\end{array}$ & $\begin{array}{l}\text { Once a } \\
\text { week }\end{array}$ & $\begin{array}{l}\text { Meeting } \\
\text { Room }\end{array}$ \\
\hline & $\begin{array}{c}\text { Incorrect } \\
\text { arrangement of } \\
\text { deckle bars and } \\
\text { forming plates }\end{array}$ & $\begin{array}{l}\text { Thickness of the edge area } \\
\text { is thick and thin }\end{array}$ & $\begin{array}{l}\text { Setting the deckle bar and forming } \\
\text { plates according to the SOP of the } \\
\text { FPT-PRD-005 extrusion machine } \\
\text { on how to deal with irregularities }\end{array}$ & Operator & $\begin{array}{c}\text { Each oil } \\
\text { pack } \\
\text { lamination }\end{array}$ & $\begin{array}{c}\text { Extrusion } \\
\text { lamination } \\
\text { machine } 5\end{array}$ \\
\hline \multirow[t]{8}{*}{$\begin{array}{c}\text { Material } \\
\mathrm{s}\end{array}$} & \multirow[t]{2}{*}{$\begin{array}{l}\text { Rigid PET film } \\
\text { characters }\end{array}$} & \multirow[t]{2}{*}{ Uneven film flow } & $\begin{array}{l}\text { Make changes to tension settings } \\
\text { adjusted to the type of film }\end{array}$ & Operator & $\begin{array}{l}\text { Each oil } \\
\text { pack } \\
\text { lamination }\end{array}$ & $\begin{array}{l}\text { Extrusion } \\
\text { lamination } \\
\text { machine } 5\end{array}$ \\
\hline & & & Adjust the banana roll slowly & Operator & $\begin{array}{c}\text { Each oil } \\
\text { pack } \\
\text { lamination }\end{array}$ & $\begin{array}{c}\text { Extrusion } \\
\text { lamination } \\
\text { machine } 5 \\
\end{array}$ \\
\hline & \multirow[t]{3}{*}{$\begin{array}{l}\text { Trim Edge } \\
\text { material is not } \\
\text { cut and entered } \\
\text { into the roll }\end{array}$} & Trimming roll is defective & $\begin{array}{l}\text { Perform replacement trimming roll } \\
\text { with conditions that are still good } \\
\text { and prepare ready-made trimming } \\
\text { spare parts }\end{array}$ & $\begin{array}{l}\text { Engineerin } \\
\mathrm{g}\end{array}$ & $\begin{array}{c}\text { Januari } \\
2019\end{array}$ & $\begin{array}{l}\text { Extrusion } \\
\text { lamination } \\
\text { machine } 5\end{array}$ \\
\hline & & $\begin{array}{l}\text { Blunt Trim Edge blade } \\
\text { conditions and clogged } \\
\text { Trim Blower Wind } \\
\text { Blowers }\end{array}$ & $\begin{array}{c}\text { Replace Trim Edge knives } \\
\text { immediately if problems occur } \\
\text { every } 2 \text { days and Verify the TE } \\
\text { blade replacement form in the field } \\
\text { is done according to schedule and } \\
\text { Repair Trim Edge wind blowers and } \\
\text { stop the process temporarily }\end{array}$ & $\begin{array}{l}\text { Operator } \\
\text { dan SPV } \\
\text { Produksi } \\
\text { Laminasi }\end{array}$ & $\begin{array}{c}\text { Januari } \\
2019\end{array}$ & $\begin{array}{l}\text { Extrusion } \\
\text { lamination } \\
\text { machine } 5\end{array}$ \\
\hline & & $\begin{array}{l}\text { Trimming roll and Trim } \\
\text { Edge blade settings are } \\
\text { incorrect }\end{array}$ & $\begin{array}{c}\text { Repairing pneumatic pressure } \\
\text { blades Trim Edge }\end{array}$ & $\begin{array}{l}\text { Engineerin } \\
\mathrm{g}\end{array}$ & $\begin{array}{c}\text { Januari } \\
2019\end{array}$ & $\begin{array}{l}\text { Extrusion } \\
\text { lamination } \\
\text { machine } 5 \\
\end{array}$ \\
\hline & \multirow{2}{*}{$\begin{array}{l}\text { The resin } \\
\text { character of each } \\
\text { lot is not the } \\
\text { same }\end{array}$} & \multirow[t]{2}{*}{$\begin{array}{l}\text { Thickness of lamination } \\
\text { becomes a variation }\end{array}$} & $\begin{array}{c}\text { Conduct die temperature } \\
\text { adjustments to areas of thick or thin } \\
\text { thickness }\end{array}$ & Operator & $\begin{array}{c}\text { Each oil } \\
\text { pack } \\
\text { lamination } \\
\end{array}$ & $\begin{array}{l}\text { Extrusion } \\
\text { lamination } \\
\text { machine } 5 \\
\end{array}$ \\
\hline & & & $\begin{array}{l}\text { Hold discussions with suppliers to } \\
\text { improve resin quality }\end{array}$ & $\mathrm{QC}$ & $\begin{array}{c}\text { Januari } \\
2019\end{array}$ & $\begin{array}{l}\text { Extrusion } \\
\text { lamination } \\
\text { machine } 5 \\
\end{array}$ \\
\hline & $\begin{array}{l}\text { There is engine } \\
\text { movement on the } \\
\text { lip die due to the } \\
\text { use of recycle } \\
\text { material }\end{array}$ & $\begin{array}{l}\text { Recycle resin quality is not } \\
\text { good }\end{array}$ & $\begin{array}{l}\text { Do not use resin recycle during the } \\
\text { process }\end{array}$ & Operator & $\begin{array}{c}\text { Januari } \\
2019\end{array}$ & $\begin{array}{l}\text { Extrusion } \\
\text { lamination } \\
\text { machine } 5\end{array}$ \\
\hline
\end{tabular}

Table-5: Improvements of the slitting processes with 5W1H

\begin{tabular}{|c|c|c|c|c|c|c|}
\hline Causes & What & Why & How & Who & When & Where \\
\hline \multirow[t]{2}{*}{ Machines } & $\begin{array}{l}\text { The condition of the bent } \\
\text { core shaft }\end{array}$ & \multirow{2}{*}{$\begin{array}{l}\text { The rewinder is } \\
\text { swinging and } \\
\text { unstable }\end{array}$} & Replace the As core shaft & engineering & Januari 2019 & $\begin{array}{c}\text { Thosin slitting } \\
\text { machine }\end{array}$ \\
\hline & $\begin{array}{c}\text { The condition of the As a } \\
\text { couple gear holder is } \\
\text { already oblique }\end{array}$ & & $\begin{array}{c}\text { Fixing As a couple gear } \\
\text { holder }\end{array}$ & engineering & Januari 2019 & $\begin{array}{c}\text { Thosin slitting } \\
\text { machine }\end{array}$ \\
\hline \multirow[t]{2}{*}{ Methods } & $\begin{array}{c}\text { Manually adjust the } \\
\text { tension which is too big } \\
\text { when the cutting process } \\
\text { is running }\end{array}$ & $\begin{array}{l}\text { Unwinder and } \\
\text { rewinder become } \\
\text { unbalanced }\end{array}$ & $\begin{array}{l}\text { Reduces tension and } \\
\text { controls during the } \\
\text { cutting process }\end{array}$ & Operator & $\begin{array}{c}\text { Every oil pack } \\
\text { production process }\end{array}$ & $\begin{array}{c}\text { Thosin slitting } \\
\text { machine }\end{array}$ \\
\hline & $\begin{array}{l}\text { Improper razor blade } \\
\text { position }\end{array}$ & $\begin{array}{l}\text { Thickness WIP } \\
\text { laminate thin edge } \\
\text { area }\end{array}$ & $\begin{array}{l}\text { Shift the razor blade } \\
\text { position to the same area } \\
\text { as the one next to it }\end{array}$ & Operator & $\begin{array}{c}\text { Every oil pack } \\
\text { production process }\end{array}$ & $\begin{array}{l}\text { Thosin slitting } \\
\text { machine }\end{array}$ \\
\hline \multirow[t]{5}{*}{ Materials } & $\begin{array}{l}\text { The use of recycled } \\
\text { paper cores }\end{array}$ & $\begin{array}{l}\text { The availability of } \\
\text { paper cores from } \\
\text { suppliers has run } \\
\text { out }\end{array}$ & $\begin{array}{l}\text { Monitoring the } \\
\text { availability of paper } \\
\text { cores for oil packs and } \\
\text { cooperation contracts } \\
\text { with suppliers }\end{array}$ & $\begin{array}{c}\text { PPIC } \\
\text { Departerment }\end{array}$ & Januari 2019 & $\begin{array}{c}\text { Raw Materials } \\
\text { (RM) paper } \\
\text { core } \\
\text { warehouse }\end{array}$ \\
\hline & \multirow[t]{2}{*}{$\begin{array}{l}\text { The thickness of the } \\
\text { laminated WIP input } \\
\text { varies }\end{array}$} & \multirow{2}{*}{$\begin{array}{l}\text { The thickness of } \\
\text { the used paper } \\
\text { core is not the } \\
\text { same }\end{array}$} & $\begin{array}{c}\text { Defaults the engine by } \\
\text { slowly adjusting speed } \\
\text { and initial tension }\end{array}$ & Operator & $\begin{array}{c}\text { Every oil pack } \\
\text { production process }\end{array}$ & $\begin{array}{l}\text { Thosin slitting } \\
\text { machine }\end{array}$ \\
\hline & & & $\begin{array}{c}\text { Inform the lamination } \\
\text { department to be repaired }\end{array}$ & Operator & $\begin{array}{c}\text { Every oil pack } \\
\text { production process }\end{array}$ & $\begin{array}{c}\text { Lamination } \\
\text { Departement }\end{array}$ \\
\hline & & & & Operator & $\begin{array}{c}\text { Every oil pack } \\
\text { production process }\end{array}$ & $\begin{array}{c}\text { Thosin slitting } \\
\text { machine }\end{array}$ \\
\hline & & & $\begin{array}{l}\text { Inform the lamination } \\
\text { department to be repaired }\end{array}$ & Operator & $\begin{array}{c}\text { Every oil pack } \\
\text { production process }\end{array}$ & $\begin{array}{l}\text { Lamination } \\
\text { Departement }\end{array}$ \\
\hline
\end{tabular}




\section{Evaluation of Improvement Results}

Evaluation is carried out to compare the conditions before improvement with after improvement by reviewing the data after the improvement is done. Thus, it can be seen that the improvement that have been made are effective or not. Evaluation is done by looking at the level of product rejects after the improvement process. Overall packaging reject and especially oil pack rejects, were compared before improvement (2018) and after improvement (2019) (Table 6).

Table-6: Comparison of rejects before improvement (2018) and after improvement (2019)

\begin{tabular}{|c|c|c|c|}
\hline \multirow{2}{*}{$\begin{array}{c}\text { Reject } \\
\text { Parameters }\end{array}$} & $\mathbf{2 0 1 8}$ & $\mathbf{2 0 1 9}$ & Analysis \\
\cline { 2 - 4 } & \multicolumn{2}{|c|}{ Percentage (\%) } & \\
\hline $\begin{array}{c}\text { Overall reject } \\
\text { (5 group) }\end{array}$ & 3.78 & 3.05 & decreased \\
\hline Oil pack reject & 3.11 & 2.52 & decreased \\
\hline $\begin{array}{c}\text { Printing reject of } \\
\text { oil pack }\end{array}$ & 0.31 & 0.19 & decreased \\
\hline $\begin{array}{c}\text { Lamination } \\
\text { reject of oil pack }\end{array}$ & 2.67 & 2.25 & decreased \\
\hline $\begin{array}{c}\text { Slitting reject of } \\
\text { oil pack }\end{array}$ & 0.12 & 0.08 & decreased \\
\hline
\end{tabular}

Source: Data processed $(2018,2019)$

The overall reject packaging performance was initially $3.78 \%$ to 3.05 which is already below the standard of $3.5 \%$. This improvement effort is not done instantly, but it is a continuous improvement. For reject oil pack, it decreased from $3.11 \%$ to $2.52 \%$. However, this value is not in accordance with the target set for oil packs of $1.5 \%$. So that further improvements are needed in order to achieve the desired reject target.

The improvement has a significant effect on dirty rejects of the printing process. The number of dirty rejects in 2018 amounted to 471 roll, in 2019 reduced to 232 roll. Through the comparison of the pareto diagram before and after the improvements, the percentage of reject decreased by $45 \%$ (Figure 10).
The results of improvements in the lamination process have a positive impact that can reduce the reject in this process by $23 \%$ (Figure 11). The improvement is focused on decreasing wrinkle and thickness because it is the most dominant reject. The improvement is quite effective in reducing wrinkle reject from 2,758 roll to 1,963 roll.

Improvements that have been made show a decrease in reject in the overall slitting process by $40 \%$ (Figure 12). The amount of sagging rejects can be reduced from 169 roll to 93 roll.

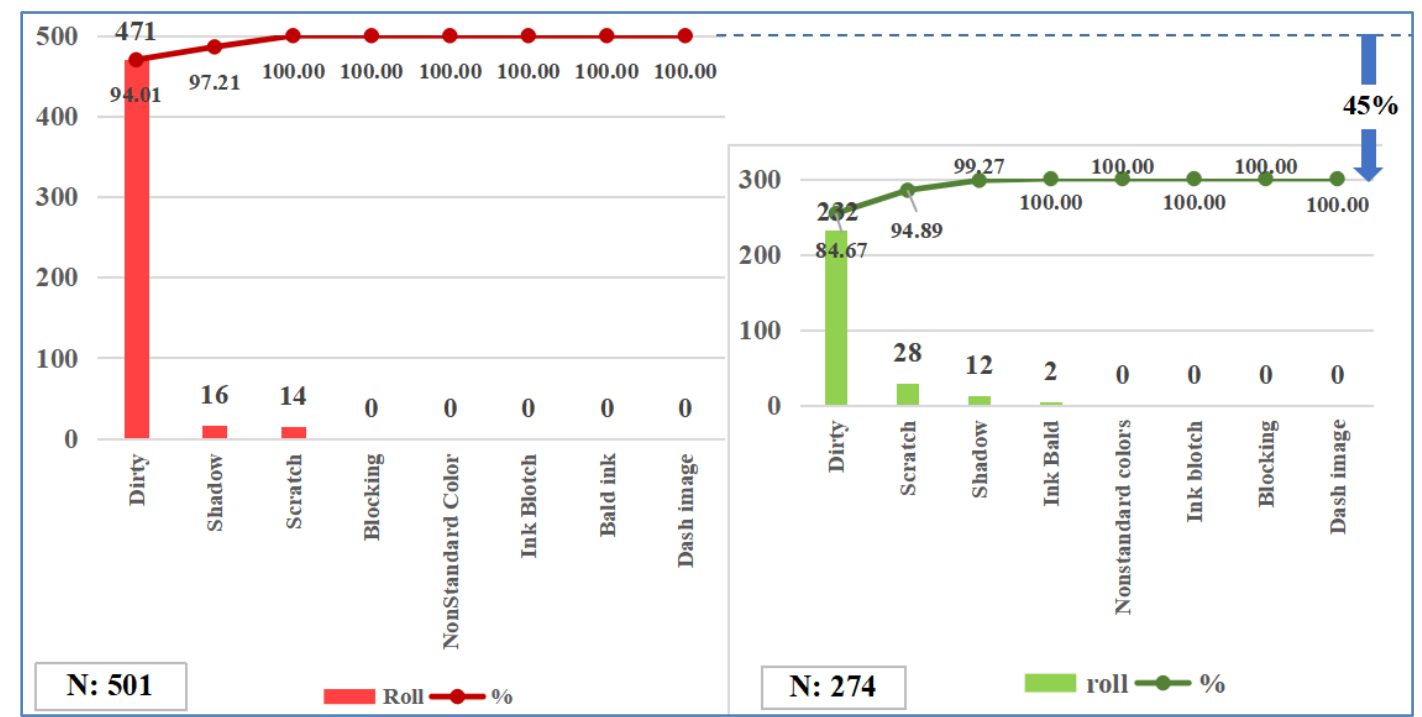

Fig-10: Comparison of the Pareto diagram on printing rejects before improvement (2019) and after improvement (2019) 


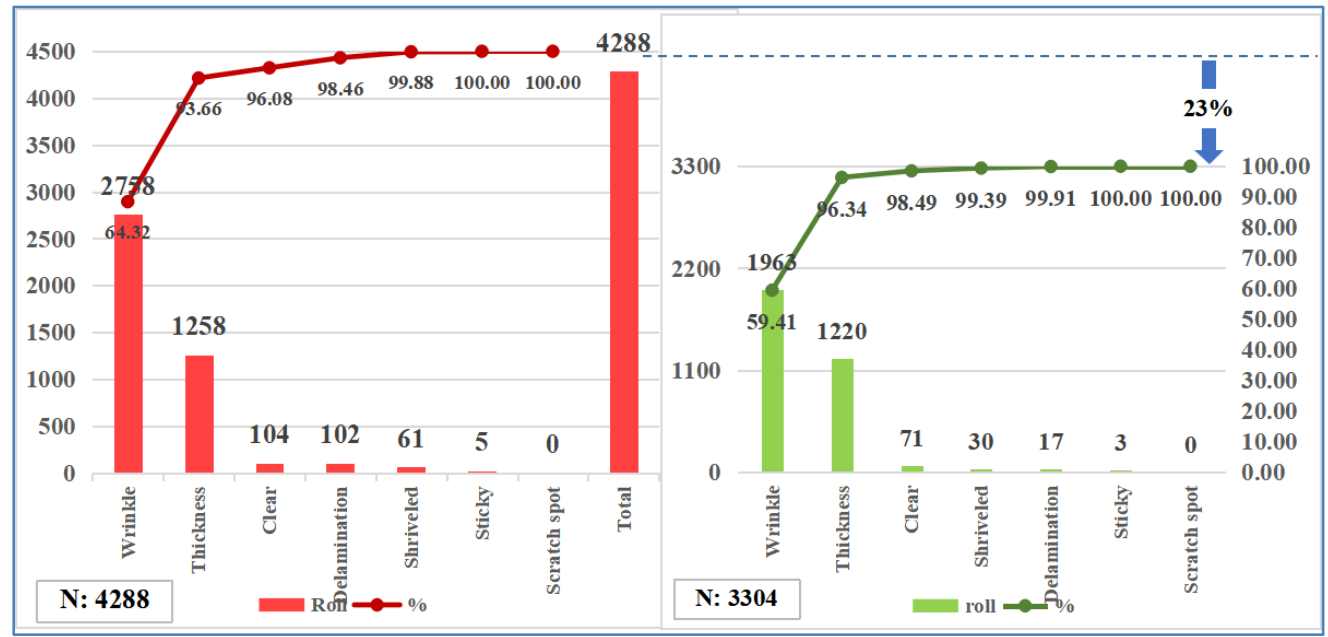

Fig-11: Comparison of the Pareto diagram on lamination rejects before improvement (2019) and after improvement (2019)

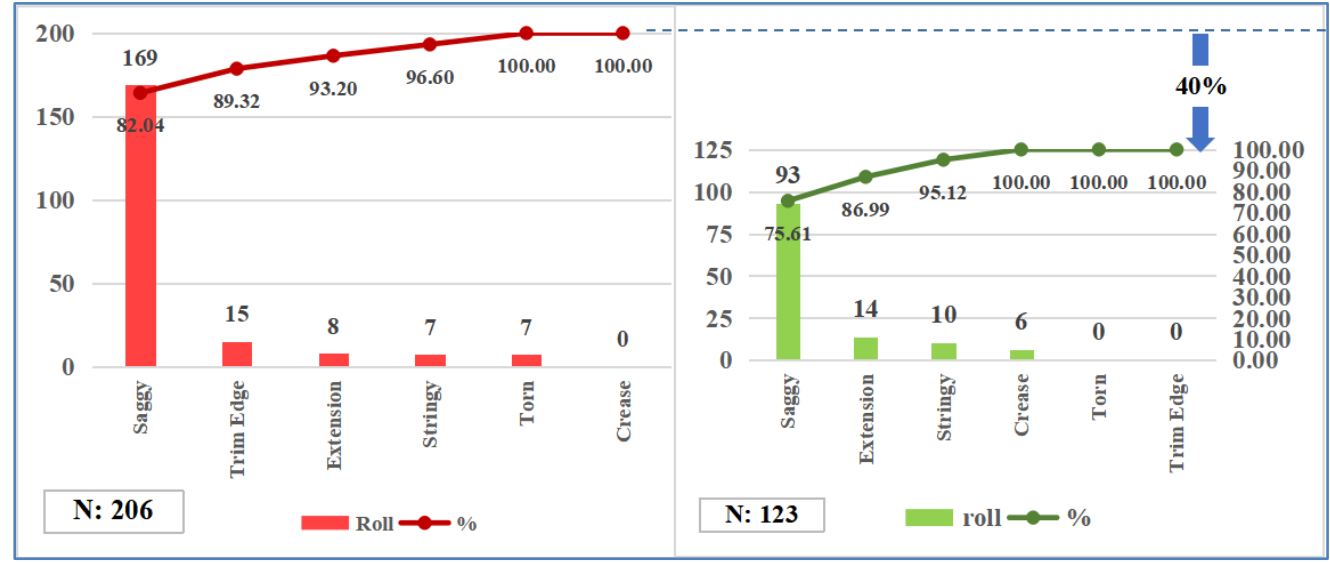

Fig-13: Comparison of the Pareto diagram on slitting rejects before (2019) and after improvement (2019)

\section{CONCLUSION}

The conclusions that can be drawn from this study are:

a. There are four factors that influence the high reject oil pack packaging, they are human factors, machine factors, method factors, and material factors. The human factor that causes rejects is the lack of operator supervision and inconsistency during the process. From the engine factor that is due to inadequate engine unit conditions and lack of maintenance. Method factors that cause are machine parameter settings and incorrect scheduling of orders. The last factor is the material factor, namely the lack of supply of raw materials and poor quality of raw materials.

b. To reduce reject oil packs, the method used is the $5 \mathrm{~W} 1 \mathrm{H}$ method. Proposed improvement of reject control is drawn from four factors. Suggestions for improvement on human-caused factors are conducting SOP briefings and making machine alarm systems. The engine factor is repairing or replacing damaged engine units and cleaning the engine units regularly. The proposed method improvement method is to set machine parameters appropriately according to the standard and set the order scheduling from long to short film sizes. Whereas the material factor is monitoring the availability and quality of raw materials, implementing a buffer stock system, and making requests for quality improvement to suppliers.

c. The results of the evaluation of improvements in the production process of oil pack packaging have a positive impact which can reduce the reject in the printing process by $45 \%$, the lamination process by $23 \%$ and the slitting process by $40 \%$.

\section{SUGGESTION}

Based on the results of the research that has been done there are a number of suggestions that need to be considered including:

- Stricter supervision is needed in the field during the lamination process when changing orders of oil packs with short to wide sizes.

- It is necessary to review the machine unit part of the lamination process as a whole which needs to be repaired and replaced by the engineering team.

- SOP (Standard Operation Procedure) pocket book is made for every process of printing, lamination, and slitting which is distributed to each operator.

- Further research needs to be done with the Six Sigma method with the DMAIC model and using FMEA improvement analysis in more detail to 
reduce the problem of rejecting oil packs so that it can achieve the desired target.

\section{REFERENCE}

1. Hariastuti, N. L. P. (2015). Analisis Pengendalian Mutu Produk Guna Meminimalisasi Produk Cacat. Seminar Nasional IENACO, 268-275.

2. Suhardi, B., Anisa, N., \& Laksono, P. W. (2009). Minimizing waste using lean manufacturing and ECRS principle in Indonesian furniture industry. Cogent Engineering. Cogent, 6, 1-13.

3. Pamungkas, T. P., Rahman, N., \& Nasution, A. (2018). Perbaikan Kualitas untuk Meminimasi Cacat Produk Foldable Lens Folder dengan Menggunakan Metode TRIZ. Prosiding Teknik Industri, 4(2), 574-581.

4. Febriana, E. K. (2017). Pengaruh Keragaman Produk, Kualitas Produk Dan Lokasi Penjualan Terhadap Kepuasan Konsumen. Journal of Management, 3(3).

5. Napitupulu, M. E. and Hati, S. W. (2018). Analisis Pengendalian Kualitas Produk Garment Pada Project in Line Inspector Dengan Metode Six Sigma Di Bagian Sewing Produksi Pada PT Bintan Bersatu Apparel Batam, Journal of Applied Business Administration, 2(1), 29-45.

6. Wahyuni, H. C., Khamim, M., \& Sulistiowati, W. (2015). Pengendalian Kualitas. Sidoarjo: Graha Ilmu.

7. Alkatiri, H. A., Adianto, H., \& Novirani, D. (2015). Implemetasi Pengendalian Kualitas Untuk Mengurangi Jumlah Produk Cacat Tekstil Kain Katun Menggunakan Metode Six Sigma Pada PT. SSP. Jurnal Online Institut Teknologi Nasional, 03(03), 148-159.

8. Realyvásquez-Vargas, A. (2018). Applying the Plan-Do-Check-Act (PDCA) cycle to reduce the defects in the manufacturing industry. A case study, Applied Sciences, 8, 1-17.

9. Srivastava, A., Kumar, V., \& Singh, A. K. (2018). Computerized and Electronic Controls in Food Packaging, Journal of Applied Packaging Research, 10, 28-45.

10. Kotler, P., \& Armstrong, G. (2015). Dasar-Dasar Pemasaran. 9th edn. Edited by Alexander Sindoro. Jakarta: Indeks.

11. Prameswari, N. S., Suharto, M., \& Wulandari, E. (2018). Strategi Branding Melalui Inovasi Desain
Kemasan bagi Home Industry Sabun Cair, Desain Komunikasi Visual, Manajemen Desain dan Periklanan, 3(2), 35-54.

12. Njoto, T. K. (2016). Pengaruh desain kemasan, cita rasa, dan variasi produk terhadap keputusan pembelian konsumen Bumi Anugerah, PERFORMA: Jurnal Manajemen dan Start-Up Bisnis, 1(4), 455-463.

13. Morris, B. A. (2017). The Science and Technology of Flexible Packaging: Multilayer Films from Resin and Process to End Use. Cambridge: Elsevier.

14. Mehra, S., Singh, A., \& Verma, S. (2017). To Study the Solid Wastages and its Minimization in Gravure Printing, International Journal of Science, Engineering and Computer Technology, 7(2), 136138.

15. Rohman, S. A. (2017) Pengembangan Produk Pelapisan Plastik Kemasan Dengan Pemanfaatan Resin Recycle Pada Proses Extrusion Laminasi, Teknobiz Journal Ilmu Program Studi Magister Teknik Mesin, 7(2), 105-114.

16. Akbar, I. A. (2019). Analisis Kerusakan Etiket dan Penyelesaian Masalah dalam Pembuatan Kemasan Plastik di PT.ICBP. Mercubuana University Repository.

17. Silva, A. S., Medeiros, C. F., \& Vieira, R. K. (2017). Cleaner Production and PDCA Cycle: Practical Application for Reducing the Cans Loss Index in a Beverage Company, Journal of Cleaner Production. Elsevier Ltd, 150, 324-338.

18. Nugroho, R. E., Marwanto, A., \& Hasibuan, S. (2017) Reduce Product Defect in Stainless Steel Production Using Yield Management Method and PDCA, International Journal of New Technology and Research (IJNTR), 3(11), 39-46.

19. Ridwansyah, M., Nusraningrum, D., \& Sutawijaya, A. H. (2019). Analisis overall equipment effectiveness untuk mengendalikan six big losses pada mesin pembuatan nugget, Open Journal Mercubuana, 3(1), 38-51.

20. Naranje, V., Naranje, A., \& Salunkhe, S. (2018). Improving Process Performance with World-Class Manufacturing Technique: A Case in Tea Packaging Industry, Innovative Design, Analysis and Development Practices in Aerospace and Automotive Engineering. Singapore: Springer, 6578. 